\title{
INFLUENCE OF NEPHROTIC STATE ON THE INFECTIOUS PROFILE IN CHILDHOOD IDIOPATHIC NEPHROTIC SYNDROME
}

\author{
Emilia Maria Dantas Soeiro, Vera Hermina Koch, Maria Danisi Fujimura and \\ Yassuhiko Okay
}

SOEIRO EMD et al. Influence of nephrotic state on the infectious profile in childhood idiopathic nephrotic syndrome. Rev. Hosp. Clín. Fac. Med. S. Paulo 59(5):273-278, 2004.

Patients with idiopathic nephrotic syndrome present alterations in their cellular and humoral immune reactions that predispose them to the development of infectious processes.

PURPOSE: To characterize the infectious processes in patients with idiopathic nephrotic syndrome.

PATIENTS AND METHODS: Ninety-two children and adolescents with idiopathic nephrotic syndrome were assessed retrospectively. The types of infection were grouped as follows: upper respiratory tract infections; pneumonia; skin infections; peritonitis; diarrhea; urinary tract infection; herpes virus; and others. The patients were divided into 2 groups: Group I (steroid-responsive) $\mathrm{n}=75$, with 4 subgroups-IA (single episode) $\mathrm{n}=10$, IB (infrequent relapsers) $\mathrm{n}=5$, IC (frequent relapsers) $\mathrm{n}=14$, and ID (steroid-dependent) $\mathrm{n}=46$; and Group II (steroid-resistant) $\mathrm{n}=17$. The incidence-density of infection among the patients was assessed throughout the follow-up period. Comparisons for each group and subgroup were done during the periods of negative and nephrotic proteinuria.

RESULTS: The analysis revealed a greater incidence-density of infections during the period of nephrotic proteinuria in all the groups and subgroups, with the exception of subgroup IA. During the period of nephrotic proteinuria, subgroups IC, ID, and Group II presented a greater incidence-density of infections as compared to subgroup IA. For the period of negative proteinuria, there was no difference in the incidence-density of infections between the groups and subgroups. Upper respiratory tract infections were the most frequent infectious processes.

CONCLUSION: The nephrotic condition, whether as part of a course of frequent relapses, steroid dependence, or steroid resistance, conferred greater susceptibility to infection among the patients with idiopathic nephrotic syndrome. The results of this study suggest that the best preventive action against infection in this disease is to control the nephrotic state.

KEY WORDS: Nephrotic syndrome. Infection. Children. Adolescent.

It has long been recognized that an immunogenic stimulus can trigger idiopathic nephrotic syndrome or cause recurrence of the disease. ${ }^{1,2}$ Abnormalities in the functions of the $\mathrm{T}$ lymphocytes and in particular the suppressor T lymphocytes and the generation of circulating factors capable of altering the glomerular permeability to proteins seem to be involved in the pathogenesis of the disease. ${ }^{3}$ The infectious episodes result from a group of alterations that synergically increase the patients' susceptibility to infections. These alterations are low serum levels of immunoglobulins, particularly $\mathrm{IgG}$, due fundamentally to low production and to a lesser extent

From the Children's Institute, Hospital das Clínicas, Faculty of Medicine, University of São Paulo - São Paulo/SP, Brazil. E-mail: mauriciosoeiro@aol.com Received for publication on November 14, 2003. to catabolism and renal losses; defect in the opsonization of bacteria; and immunosuppressive therapy., ${ }^{4,5}$

Infectious episodes in nephrotic patients are responsible for high morbidity and can also cause an inadequate response to corticosteroid therapy and recurrences among patients in remission. ${ }^{6}$ Determining the type of infection is important, not only from the therapeutic point of view, but also to establish preventive measures. ${ }^{7}$ 
Consequently, the objective of this work was to clarify whether the nephrotic state does in fact increase susceptibility of the patients to infections and, if so, to characterize the types of infections that occur in these patients.

\section{PATIENTS AND METHODS}

A retrospective analysis was done on the hospital records of 92 patients with idiopathic nephrotic syndrome who attended from January 1985 to December 1998. Each patient was evaluated throughout the follow-up in terms of period (in months) of remission with negative proteinuria and of nephrotic decompensation. For characterization of nephrotic proteinuria, the qualitative test with $10 \%$ trichloroacetic acid was used. Negative proteinuria was considered to be when there was no alteration in the color of the urine. Proteinuria +++ and ++++ were considered to be a nephrotic level for comparison with the quantitative tests. ${ }^{8}$ Eighty-eight patients used prednisone, at an initial dose of $2 \mathrm{mg} / \mathrm{kg} /$ day, for 4 to 6 weeks, then on alternate days, at the same dose, for a further 8 weeks. After that period, the dose was reduced by $0.5 \mathrm{mg} / \mathrm{kg}$, every 15 days, until suspension of the drug. The remaining 4 patients were steroid-resistant cases referred from other services for whom other immunosuppressive agents were used at the initiation of follow-up.

Fifty-two patients, including those who were steroid-resistant, steroid-dependent, or frequent relapsers, were administered cyclophosphamide at a dose of $75 \mathrm{mg} / \mathrm{m}^{2} /$ day for 8 weeks in association with prednisone. Eight patients that did not respond to cyclophosphamide received chlorambucil at a dose of $0.1 \mathrm{mg} / \mathrm{kg} /$ day for 10 weeks. Nine steroid-resistant patients received cyclosporine $\mathrm{A}$ at a dose of $4 \mathrm{mg} / \mathrm{kg} /$ day every 12 hours, initially associ- ated with prednisone. Five steroid-resistant patients were treated with cyclophosphamide pulse therapy and methylprednisolone, associated with prednisone, according to the protocol of Tune and Mendonza. ${ }^{9}$ The patients were divided into 2 groups according to their initial response to the steroid therapy: Group I (steroid-responsiveresolution of the proteinuria during the first 4 weeks of continuous daily treatment with prednisone) and Group II (steroid-resistant-no response to the continuous daily treatment with prednisone for 6 weeks). Group I was further divided into 4 subgroups: IA (single episode-without recurrences), IB (infrequent relapsers-less than 2 recurrences in the 6 months after the initial response), IC (frequent relapsers-2 or more recurrences in the 6 months after the initial response), and ID (steroiddependent-recurrence during the gradual withdrawal of prednisone or 15 days after its suspension). The incidence-density of infections was compared (number of infections/100 patients/month) in the total sample and for each of the groups and subgroups ${ }^{10}$ in the both the period with negative proteinuria and the period with nephrotic proteinuria.The infections were identified and classified into: URTI (upper respiratory tract infections-cold, sinusitis, otitis, tonsillitis, laryngitis); pneumonia; cutaneous infections (impetigo, cellulitis, and skin abscess); peritonitis; diarrhea; UTI (urinary tract infections); herpes virus (gingival stomatitis, labial herpes, herpes zoster, and chickenpox); and others (mumps, conjunctivitis, hepatitis, onychomycosis, septicemia, and osteomyelitis). The diagnoses of the infections were made according to clinical criteria and in some patients through laboratory exams. Blood cultures were performed in cases of peritonitis and septicemia. The diagnosis of UTI was defined with quantitative urine culture. The $z$ score was used to analyze the differences between the means of groups and sub-groups. ${ }^{11,12}$ The null hypothesis was rejected at the $5 \%$ confidence limit.

\section{RESULTS}

Table 1 summarizes the characteristics of all 92 patients regarding their response to corticoid, sex, age, and duration of follow-up. The incidencedensity of infections for the 92 patients in the period with nephrotic proteinuria was 52.98 infections $/ 100$ patients/month. In the 89 patients that presented a period of negative proteinuria, this coefficient was 3.9 infections/100 patients/month $(z=-8.775$ and $P<.001)$. Three patients in Group II maintained nephrotic proteinuria throughout the entire follow-up. Graph 1 shows the number and type of infection in the 92 patients during the period with nephrotic proteinuria (604 infections/1140 months) and of the 89 patients, in the period with negative proteinuria (266 infections/6822 months). Upper respiratory tract infections were the most frequent infectious processes. There were 12 episodes of peritonitis in 7 patients, all in the period with nephrotic proteinuria. In these patients, streptococcus was the predominant pathogen (Streptococcus pneumoniae, 4 cases; Streptococcus viridans, 3 cases; and Enterobacter sp, 1 case), and the blood culture was negative in 4 cases. Nine episodes of UTI occurred in 8 patients. The pathogens identified in the urine cultures were: Escherichia coli in 4 cases, and 1 case each of Enterobacter species, Enterobacter cloacae, Klebsiela species, Klebsiela oxytoca, and negative coagulase Staphylococcus. Out of the 9 episodes, 7 occurred in the period with nephrotic proteinuria. The incidence-density of infections in the groups and subgroups during the periods with nephrotic proteinuria and 
Table 1 - Characteristics of the 92 patients in relation to type of response to steroid therapy, sex, age, and period of followup.

\begin{tabular}{|c|c|c|c|c|c|}
\hline & Subgroups & $\mathrm{n}$ & Sex & Age* & $\begin{array}{l}\text { Follow-up period* } \\
\text { (months) }\end{array}$ \\
\hline \multirow{8}{*}{$\begin{array}{l}\text { Steroid-responsive } \\
\text { Group I }\end{array}$} & Single episode & 10 & $7 \mathrm{M} / 3 \mathrm{~F}$ & 5.8 & 113 \\
\hline & IA & & & $(3 \mathrm{yr}-12 \mathrm{yr})$ & $(53-156)$ \\
\hline & Infrequent relapsers & 5 & $1 \mathrm{M} / 4 \mathrm{~F}$ & 4.2 & 121 \\
\hline & IB & & & $(2 \mathrm{yr}-4 \mathrm{yr} 10 \mathrm{~m})$ & $(22-180)$ \\
\hline & Frequent relapsers & 14 & $11 \mathrm{M} / 3 \mathrm{~F}$ & 3.9 & 107 \\
\hline & IC & & & $(1 \mathrm{yr}-6 \mathrm{yr} 10 \mathrm{~m})$ & $(27-166)$ \\
\hline & Steroid-dependent & 46 & $31 \mathrm{M} / 15 \mathrm{~F}$ & 4.9 & 93.1 \\
\hline & ID & & & $(1 \mathrm{yr} 4 \mathrm{~m}-10 \mathrm{yr} 11 \mathrm{~m})$ & $(16-180)$ \\
\hline Steroid-resistant & 17 & $13 \mathrm{M} / 4 \mathrm{~F}$ & 6.5 & 53.6 & $(2,150)$ \\
\hline
\end{tabular}

$\mathrm{n}=$ number of patients; $*$ data given as mean and range

negative proteinuria is shown in Table 2. Only Subgroup IA failed to show a significant reduction in the number of infections. The comparison of the incidence-density of infections between groups and subgroups in the period with nephrotic proteinuria is shown in Table 3. Subgroups IC, ID, and Group
II, presented the highest incidencedensity of infections when compared to Subgroup IA. The other comparisons did not show a statistically significant difference. The comparison of the incidence-density of infections between the groups and subgroups during the period with negative proteinu-

Table 2 - Comparison of the incidence-density of infections (number of infections/ 100 patients/month) during the periods with nephrotic proteinuria and with negative proteinuria.

\begin{tabular}{ccccc}
\hline $\begin{array}{c}\text { Groups and } \\
\text { Subgroups }\end{array}$ & $\begin{array}{c}\text { Nephrotic } \\
\text { Proteinuria }\end{array}$ & $\begin{array}{c}\text { Negative } \\
\text { Proteinuria }\end{array}$ & $(z$ score $)$ & $(P)$ \\
\hline I & 55.26 & 3.81 & -8.365 & $<.001^{*}$ \\
IA & 15.79 & 1.36 & -1.192 & .117 \\
IB & 42.86 & 1.61 & -1.806 & $.035^{*}$ \\
IC & 53.40 & 3.44 & -3.520 & $<.001^{*}$ \\
ID & 57.48 & 5.09 & -6.569 & $<.001^{*}$ \\
II & 45.49 & 4.99 & -3.021 & $.001^{*}$ \\
\hline
\end{tabular}

* Statistic significance

Table 3 - Comparison of the number of infections/100 patients/month, during the period with nephrotic proteinuria.

\begin{tabular}{cccc}
\hline $\begin{array}{c}\text { Groups and } \\
\text { Subgroups }\end{array}$ & $\begin{array}{c}\text { Number of } \\
\text { Infections/100 } \\
\text { Patients/Month }\end{array}$ & $(z$ score $)$ & $(P)$ \\
\hline I X II & $55.26 \times 45.49$ & -0.731 & .232 \\
IA X IB & $15.79 \times 42.86$ & 1.085 & .139 \\
IA X IC & $15.79 \times 53.40$ & 2.134 & $.016^{*}$ \\
IA X ID & $15.79 \times 57.48$ & 3.056 & $.031^{*}$ \\
IA X II & $15.79 \times 45.49$ & 1.779 & .342 \\
IB X IC & $42.86 \times 53.40$ & 0.408 & .265 \\
IB X ID & 42.86 X 57.48 & 0.628 & .458 \\
IB X II & 42.86 X 45.49 & 0.104 & .394 \\
IC X ID & $53.40 \times 57.48$ & 0.269 & .330 \\
IC X II & $53.40 \times 45.49$ & -0.440 & .198 \\
ID X II & $57.48 \times 45.49$ & -0.850 & \\
\hline
\end{tabular}

ria is shown in Table 4. There was no statistically significant difference in the comparison of the incidence-density of infections between the groups and subgroups throughout this period.

\section{DISCUSSION}

Infections in patients with nephrotic syndrome have been described as hallmarks of idiopathic nephrotic syndrome (INS). ${ }^{4}$ In the past, many children with nephrotic syndrome died from bacterial infections and particularly from peritonitis due to pneumococci. ${ }^{13}$ With the advent of antibiotic therapy and corticotherapy in the last 50 years, much progress has been achieved, with a dramatic reduction in the mortality. ${ }^{14}$ Despite the improvement in the morbidity rates and mortality in INS following the introduction of corticotherapy and other immunosuppressants, it is still necessary to keep in mind that these agents can also predispose patients to infectious processes. ${ }^{14,15}$ Even so, the use of these drugs serves to maintain the patients free from recurrences and to control proteinuria for prolonged periods. ${ }^{15}$ This study showed a greater density of infections during the period with nephrotic proteinuria. The comparative analysis between the 2 groups and subgroups during this period re- 
Table 4 - Comparison of the number of infections/100 patients/month, during the period with negative proteinuria.

\begin{tabular}{cccc}
\hline $\begin{array}{c}\text { Groups and } \\
\text { Subgroups }\end{array}$ & $\begin{array}{c}\text { Number of } \\
\text { Infections/100 } \\
\text { Patients/Month }\end{array}$ & $(z$ score $)$ & $(P)$ \\
\hline I X II & $3.81 \times 4.99$ & 0.190 & .424 \\
IA X IB & 1.36 X 1.61 & 0.037 & .485 \\
IA X IC & 1.36 X 3.44 & 0.341 & .367 \\
IA X ID & 1.36 X 5.09 & 0.761 & .223 \\
IA X II & 1.36 X 4.99 & 0.527 & .299 \\
IB X IC & 1.61 X 3.44 & 0.246 & .403 \\
IB X ID & 1.61 X 5.09 & 0.535 & .338 \\
IB X II & 1.61 X 4.99 & 0.418 & .389 \\
IC X ID & $3.44 \times 5.09$ & 0.282 & .419 \\
IC X II & 3.44 X 4.99 & 0.204 & .494 \\
ID X II & 5.09 X 4.99 & -0.014 & \\
\hline
\end{tabular}

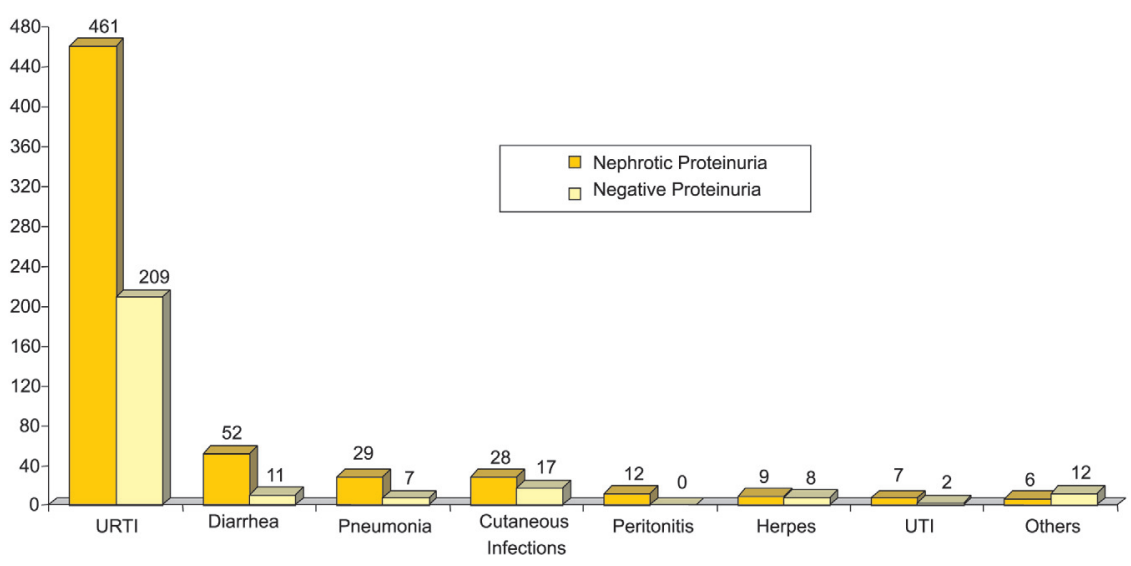

Figure 1 - Number and type of infection of 92 patients during the period with nephrotic proteinuria (604 infections/1140 months) and of the 89 patients during the period with negative proteinuria (266 infections /6822 months).

vealed higher densities of infections in the subgroups comprising frequent relapsers (IC), corticodependent (ID), and corticoresistant patients (Group II), relative to Subgroup IA (patients presenting a single nephrotic episode), a finding that is similar to the findings of Gulati et al. ${ }^{7}$ The International Study of Kidney Disease in Children has suggested that the greater vulnerability to infections and resistance to corticosteroids could have a common biological origin. ${ }^{15} \mathrm{~A}$ recent study by Moorani et al. ${ }^{16}$ points to URTI, cellulites, diarrhea, UTI, and peritonitis as the most frequent infections and that the majority are associated with decompensation of the disease. In the various published results, the type of infection is variable. The comparison of our results with other studies is somewhat difficult, since our sample is predominantly comprised of outpatients.

Upper respiratory tract infections were the most frequent infectious processes in all of the groups and subgroups during both periods. There is evidence that multiple factors have favored a higher occurrence of respiratory infections in the last 30 years. ${ }^{17}$ In the city of São Paulo, a rate of 11.8 episodes of respiratory infections can be expected per child/year among children of up to 5 years of age. ${ }^{18}$

The onset of nephrotic syndrome or recurrence of the disease can be associated with a nonspecific infection that affects the child. Studies have reported that the decompensation of the nephrotic syndrome is related to viral infections of the upper airways and that there is a causal relationship, in that the altered response to infection could be the triggering factor for the disease. $^{6}$

We found 12 peritonitis episodes in 7 patients, all with nephrotic proteinuria. The predominant pathogen was Streptococcus pneumoniae.

Pneumococcal infections in children with nephrotic syndrome are the most common invasive bacterial infections. Since 1985, the use of pneumococcal polysaccharide vaccine has been recommended for those children at greater risk of developing streptococcal infections. However, the effectiveness of this preventive measure is limited. ${ }^{19,20}$ Recently, the response to conjugated pneumococcal vaccine in patients with nephrotic syndrome has been studied, but the results are still under evaluation. ${ }^{20}$

This is the first study in Brazil that evaluates the profile of infections in children and adolescents with nephrotic syndrome. It is possible that knowledge of the etiological profile of the infections in patients with INS could lead to the introduction of new vaccines for the routine care of these patients, seeking to minimize avoidable infectious processes. Nevertheless the chief conclusion of this study is that the best preventive measure for control of the infectious processes in INS continues to be resolution of the proteinuria. 
SOEIRO EMD e col. Pacientes com síndrome nefrótica idiopática apresentam alterações na imunidade celular e humoral que predispõem a processos infecciosos. Rev. Hosp. Clín. Fac. Med. S. Paulo 59(5):273-278, 2004.

OBJETIVO: Caracterizar as infecções, em pacientes com Síndrome Nefrótica Idiopática .

PACIENTES E MÉTODOS: Foram analisados, os prontuários de 92 crianças e adolescentes com Síndrome Nefrótica Idiopática . Os tipos de infecções foram agrupados em: Infecções de Vias Aéreas Superiores, Pnemonia, Infecções Cutâneas, Peritonite, Diarréia, Infecção do Trato Urinário, Herpes Vírus e Outros. Os pacientes foram divididos, em dois grupos: Grupo I (córtico- sensíveis)-n=75, com quatro subgrupos; IA (episódio único)-n=10; IB (recidivantes infreqüentes)- $n=5$; IC (recidivantes freqüentes)- $\mathrm{n}=14$ e ID (córtico-dependentes) $\mathrm{n}=46$; e Grupo II (córtico-resistentes)-n=17. Comparou-se a densidade de incidência de infecções nos períodos com proteinúria negativa e nefrótica. No período com proteinúria nefrótica, comparou-se a densidade de incidência de infecções dos grupos e subgrupos entre si. Da mesma forma, no período com proteinúria negativa.

RESULTADO: A análise revelou maior densidade de incidência de infecções, no período com proteinúria nefrótica, em todos os grupos e subgrupos, com exceção do subgrupo IA. No período com proteinúria nefrótica, os subgrupos IC, ID e o grupo II, apresentaram maior densidade de incidên- cia de infecções, quando comparados ao subgrupo IA. No período com proteinúria negativa, não houve diferença na densidade de incidência de infecções entre os grupos e subgrupos. As Infecções de Vias Aéreas Superiores foram os processos infecciosos mais freqüentes.

CONCLUSÃO: O estado nefrótico, manifesto através de recidivas freqüentes, dependência ou resistência aos corticosteróides, conferiu ao pacientes com Síndrome Nefrótica Idiopática , maior susceptibilidade à infecções. $\mathrm{O}$ resultado deste estudo reforça que a melhor prevenção anti-infecciosa nesta doença é o controle do estado nefrótico.

UNITERMOS: Síndrome Nefrótica. Infecção. Criança. Adolescência.

\section{REFERENCES}

1. Shalhoub RJ. Pathogenesis of lipoid nephrosis: a disorder of Tcell function. Lancet.1974;2:556-60.

2. Michael AF, Mclean HR, Roy LP,Westberg NG,Hoyer JR, Fish AJ, et al. Immunologic aspects of the nephrotic syndrome. Kidney Int. 1973;3:105-15.

3. Eduardo HG. Effect of lipoid nephrosis cytokine on glomerular sulfated compounds and albuminuria. Pediatr Nephrol 1995;9:587-93.

4. Schnaper HW. Immunization practices in childhood nephrotic syndrome: a survey of North American pediatric nephrologists. Pediatr Nephrol 1994;8:4-6.

5. Harris RC, Ismail N. Extrarenal complications of the nephrotic syndrome. Am J Kidney Dis 1994;23:477-97.

6. McDonald NE, Wolfish N, Mclaine P, Phipps P, Rossier E. Role of respiratory viruses in exacerbation of primary nephrotic syndrome. J Pediatr 1986;108:378-82.

7. Gulati S, Kher V, Gupta A, Arora P, Ray PK, Sharma RK. Spectrum of infections in Indian children with nephrotic syndrome. Pediatr Nephrol 1995;9:431-4.

8. Kasiske B1, Keane WF. Laboratory assessment of renal diseases: clearance, urinalysis and renal biopsy. In: BRENER BM. The Kidney. $5^{\text {th }}$ ed. Philadelphia, Saunders, 1996, 1137-74.
9. Tune BM, Lieberman E, Mendoza AS. Steroid-resistant nephrotic focal segmental glomerulosclerosis: a treatable disease. Pediatr Nephrol 1996;10:772-8.

10. Fletcher RH, Fletcher SW, Wagner EH. Epidemiologia Clínica: Elementos Essenciais. 3rd ed. Porto Alegre, Artmed, 1996,84102.

11. Guedes MS, Guedes JS. Bioestatística para profissionais de saúde. Rio de Janeiro, Ao livro técnico, CNPq, 1988.

12. Horan TC. How to compare SSI rates using aggregated data from the NNIS system. Center For Disease Control And Prevention, 1993. Available at: www.CDC.gov

13. Orth SR, Ritz E. The nephrotic syndrome. N Eng J Med 1998;23:1202-11.

14. Melvin T, Bennett W. Management of nephrotic syndrome in childhood. Drugs 1991;42:30-51.

15. International Study Of Kidney Disease In Children. Pediatrics 1984;73:497-501.

16. Moorani KN, Khan KM, Ramzan A. Infection in children with nephrotic syndrome. J Coll Physicians Surg Pak 2003;13:3379.

17. Rizzo MC. O impacto do meio ambiente no trato respiratório. J Pediatr 1998;74 (Suppl 1):13-20. 
18. Monteiro CA. Saúde e Nutrição das Crianças de São Paulo. São Paulo, Hucitec e Editora da Universidade de São Paulo; 1988.

19. Mcintry P, CRAIG JC. Prevention of serious bacterial infection in children with nephrotic syndrome. J Paediatr Child Health 1998;34:314-7.
20. Overturf GD. American Academy of Pediatrics. Committee on Infectious Disease Technical Report: prevention of pneumococcal infections, including the use of pneumococcal conjugate and polysaccharide vaccines and antibiotic prophylaxis. Pediatrics 2000;106:367-76. 